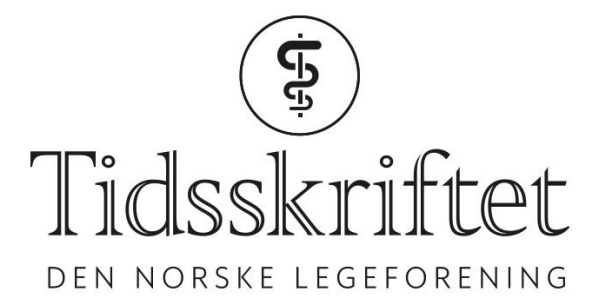

\title{
Benzodiazepiner i akuttpsykiatrisk behandling
}

DEBATT

ARNE VAALER

E-post: arne.e.vaaler@ntnu.no

Arne Vaaler er overlege ved psykiatrisk akuttseksjon, St. Olavs hospital og professor ved NTNU. Forfatteren har fylt ut ICMJE-skjemaet og oppgir ingen interessekonflikter.

Helsedirektoratets vedtak om at benzodiazepiner ikke kan brukes i akuttpsykiatrisk behandling uten pasientens samtykke, fører til dårligere behandling for pasientene.

I et brev til fylkesmennene orienterer Helsedirektoratet om at vedtak etter psykisk helsevernloven § 4-4 ikke omfatter benzodiazepiner (1). For det første viser direktoratet til risiko for toleranse- og avhengighetsutvikling, for det andre at medikamentell tvangsbehandling kun kan igangsettes og gjennomføres når det med stor sannsynlighet kan føre til helbredelse, vesentlig bedring av sykdommen eller at pasienten unngår vesentlig forverring. Det kreves derfor mer enn alminnelig sannsynlighetsovervekt for positiv effekt på den alvorlige sinnslidelsen (psykosen). Helsedirektoratet har det syn at benzodiazepiner gjennomgående ikke oppfyller dette strenge kravet. De skriver at benzodiazepiner ikke behandler psykosesymptomene direkte, men brukes mot symptomer som angst, uro, søvnvansker og agitasjon (1).

Realiteten i en psykiatrisk hverdag er at mesteparten av pasientene legges inn med sammensatte psykiatriske tilstander. Pasientene er ofte preget av akutte livskriser komplisert av rusmiddelbruk, abstinens og polyfarmasi, og de har ofte flere psykiatriske og somatiske problemstillinger (2). Halvparten av pasientene som akuttinnlegges i psykiatriske avdelinger, er påvirket av flere rusmidler samtidig (3).

\section{Benzodiazepiner ved ulike tilstander}

I internasjonale retningslinjer anbefales benzodiazepiner ved en rekke akuttpsykiatriske tilstander inkludert psykoser med eller uten komorbid ruslidelse, (4). Grunnen til dette er at benzodiazepiner er effektive og trygge valg. I henhold til norske retningslinjer er antipsykotika primærbehandling ved psykoser. Ved en rekke tilstander, også hos pasienter med symptomer på psykose, vil imidlertid bruk av antipsykotika medføre økt fare for pasientene. Noen pasienter vil settes i akutt livsfare, for eksempel ved symptomer på katatoni (5). Flere typer rusmidler som amfetaminer, hallusinogener og opiater gir økt fare for alvorlige bivirkninger ved bruk av antipsykotika (6). En rekke organiske psykiatriske tilstander har akutte eller kroniske psykoser som kjernesymptom. Generelt bør det utvises forsiktighet med bruk av antipsykotika til pasienter med for eksempel traumatisk hjerneskade (7). Hvis organiske, psykotiske tilstander er utløst av paroksysmale cerebrale 
hyperaktivitetstilstander, vil antipsykotika senke krampeterskelen og ha potensial til å øke epileptiform aktivitet og dermed forlenge og ytterligere forverre en akutt psykose.

Noen pasientgrupper i psykiatriske avdelinger har høy/økt forekomst av selvmord under innleggelse og rett etter utskrivning (8). Disse pasientene er preget av agitasjon, panikk, desperasjon og av og til psykose (9). De siste 20 årene har vi fătt kunnskap om at den primære suicidforebyggende behandlingen for denne gruppen bør være å sikre adekvat behandling av angst og søvn (10). Benzodiazepiner er et åpenbart førstevalg.

\section{Manglende forståelse}

Det er uklart hva Helsedirektoratet mener med «å behandle psykosesymptomer direkte» (1). Ved for eksempel depressive psykoser er medfølgende angst, agitasjon og søvnløshet ikke bare utløsende for selvmord, det er en del av det affektive syndromet. Organiske psykoser kan utløses av for eksempel endret cerebral elektrofysiologisk aktivitet som ved epilepsi (11). Direkte psykosebehandling er å stoppe slik aktivitet med benzodiazepiner og stemningsstabiliserende antiepileptika.

Faren for misbruk ved benzodiazepiner er liten både ved kortere og lengre tids behandling (12). De aller fleste pasienter misbruker ikke, de øker ikke dosen selv ved langtidsbehandling for angstlidelser. Pasientene $\emptyset$ nsker benzodiazepiner fordi det hjelper på en rekke symptomer, inkludert "psykose».

Konklusjonen er at Helsedirektoratet med sitt vedtak fratar mange pasienter en trygg, skånsom, og effektiv behandling. Det fratar pasientene en behandling de selv $\emptyset$ nsker. Vedtaket er basert på manglende vurdering av kompleksiteten i den psykiatriske hverdagen.

\section{LITTERATUR:}

1. Brev til landets kontrollkommisjoner fra Helsedirektoratet. 12.2.2019.

https://helsedirektoratet.no/Documents/Lovfortolkninger/Psykisk\%2ohelsevernloven/Svar\%2op\%C3\%A 5\%20sp\%C3\%B8rsm\%C3\%A51\%20om\%2obehandling\%2outen\%2oeget\%2osamtykke\%2C\%2obenzodiazepin er\%20og\%2otabletter\%2of\%C3\%B8r\%2oinjeksjon.pdf(27.3.2019).

2. Zealberg JJ, Brady KT. Substance abuse and emergency psychiatry. Psychiatr Clin North Am 1999; 22: 803-17. [PubMed][CrossRef]

3. Mordal J, Holm B, Mørland J et al. Recent substance intake among patients admitted to acute psychiatric wards: physician's assessment and on-site urine testing compared with comprehensive laboratory analyses. J Clin Psychopharmacol 2010;30: 455-9. [PubMed][CrossRef]

4. Allen MH, Currier GW, Hughes DH et al. Treatment of behavioral emergencies: a summary of the expert consensus guidelines. J Psychiatr Pract 2003; 9: 16-38. [PubMed][CrossRef]

5. Daniels J. Catatonia: clinical aspects and neurobiological correlates. J Neuropsychiatry Clin Neurosci 2009; 21:371-80. [PubMed][CrossRef]

6. Toce MS, Chai PR, Burns MM et al. Pharmacologic treatment of opioid use disorder: a review of pharmacotherapy, adjuncts, and toxicity. J Med Toxicol 2018; 14:306-22. [PubMed][CrossRef]

7. Plantier D, Luauté J. Drugs for behavior disorders after traumatic brain injury: Systematic review and expert consensus leading to French recommendations for good practice. Ann Phys Rehabil Med 2016; 59: 42-57. [PubMed][CrossRef]

8. Walby FA, Myhre M $\varnothing$, Kildahl AT. Contact with mental health services prior to suicide: A systematic review and meta-analysis. Psychiatr Serv 2018; 69: 751-9. [PubMed][CrossRef]

9. Fredriksen KJ, Schoeyen HK, Johannessen JO et al. Psychotic depression and suicidal behavior. Psychiatry 2017; 80: 17-29. [PubMed][CrossRef]

10. Goodwin FK. Preventing inpatient suicide. J Clin Psychiatry 2003; 64: 12-3. [PubMed][CrossRef]

11. Brewerton TD. The phenomenology of psychosis associated with complex partial seizure disorder. 
Ann Clin Psychiatry 1997; 9:31-51. [PubMed][CrossRef]

12. Starcevic V. The reappraisal of benzodiazepines in the treatment of anxiety and related disorders. Expert Rev Neurother 2014; 14: 1275-86. [PubMed][CrossRef]

Publisert: 6. mai 2019. Tidsskr Nor Legeforen. DOI: 10.4045/tidsskr.19.0228

Mottatt 17.3.2019, første revisjon innsendt 26.3.2019, godkjent 28.3.2019.

(C) Tidsskrift for Den norske legeforening 2020. Lastet ned fra tidsskriftet.no 